Goldschmidt 2021 Abstract

https://doi.org/10.7185/gold2021.5956

\section{Petrogenesis of tonalite-dominated intrusive suites of the Abitibi greenstone belt}

\section{MS. LUCIE MATHIEU}

Université du Québec à Chicoutimi (UQAC)

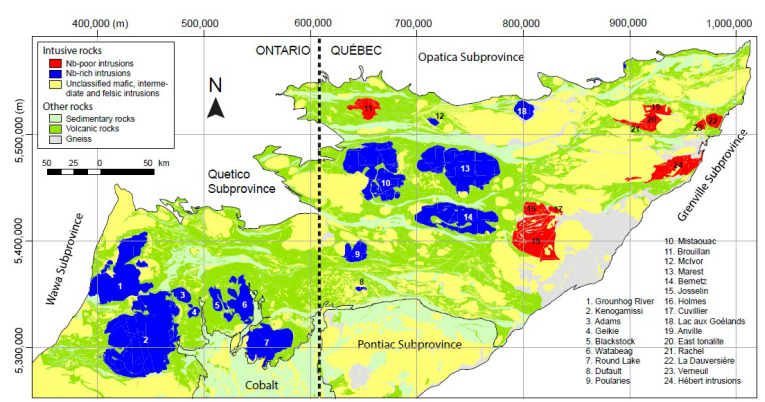

Presenting Author: lucie1.mathieu@uqac.ca

In Archean greenstone belts, such as the Neoarchean Abitibi belt $(>2.79$ to $\sim 2.65 \mathrm{Ga}$ ), Superior craton, Canada, felsic magmatism is dominated by large-volume batholiths, i.e., tonalite-trondhjemite-granodiorite (TTG) and tonalitetrondhjemite-diorite (TTD) suites. Insights into the source and partial melting conditions of such intrusive suites provide essential constraints on the tectonic regimes prevailing before 2.5 Ga. Most petrogenetic interpretations rely on whole-rock chemical data. For example, and using a compilation of whole rock chemical data, two coeval magmas were uncovered in the Abitibi belt: 1) a heavy rare earth elements (HREE)-depleted tonalitic magma from high pressure melting of an hydrated basalt source (TTG suite); and 2) a hybrid HREE-undepleted magma that may be a mixture of mantle-derived (tholeiite) and tonalitic melts (TTD suite). Such petrogenetic interpretations, however, tend to neglect the role of differentiation on primitive melt composition. This study used numerical modeling to provide quantitative constraints on the fractional crystallization of TTG suites and to demonstrate that differentiation can significantly affect the chemistry of these magmas. Amphibole fractionation alone is sufficient to explain the range of HREE observed in TTG suites of the Abitibi greenstone belt. As well, the fractional crystallization of amphibole under various temperature conditions explains the contrasting $\mathrm{Nb}$ and $\mathrm{Ti}$ contents of the studied intrusive phases. Neoarchean tonalite-dominated magmatism likely results from a diversity of petrogenetic processes. Deducing partial melting depth using whole-rock analyses is possible but requires a profound understanding of differentiation processes. The petrogenesis of individual intrusions should thus be interpreted with caution before drawing conclusions on source processes and, by extension, the geodynamic settings.

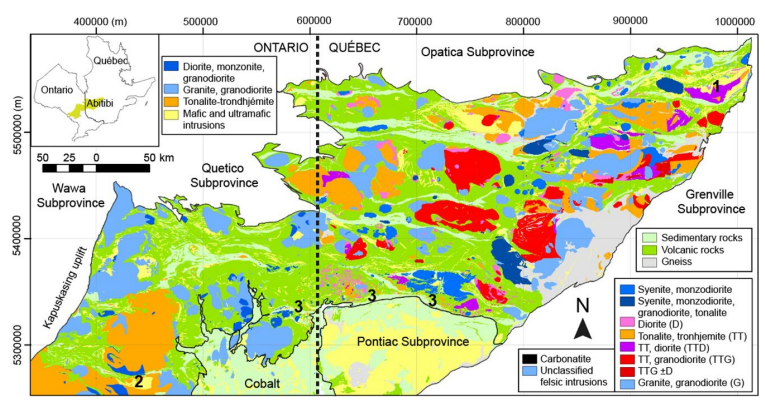

